\title{
Management of Educational Projects on the Example of Accreditation of Educational Programs
}

\author{
Nadiia Kuzmenko ${ }^{1, *}$, Yaroslav Kichuk ${ }^{2}$, Tetiana Lesina ${ }^{3}$, Liudmyla Levytska ${ }^{1}$, Nataliia Kostrytsia ${ }^{4} \&$ Nataliia \\ Mazur $^{5}$ \\ ${ }^{1}$ Department of Pedagogy, Taras Shevchenko National University of Kyiv, Kyiv, Ukraine \\ ${ }^{2}$ Department of Law and Social Work, Izmail State University of Humanities, Izmail, Ukraine \\ ${ }^{3}$ Department of Preschool and Primary Education, Izmail State University of Humanities, Izmail, Ukraine \\ ${ }^{4}$ Department of Journalism and Language Communication, National University of Life and Environmental Sciences \\ of Ukraine, Kyiv, Ukraine \\ ${ }^{5}$ National Commission on State Language Standards, Kyiv, Ukraine \\ *Correspondence: Department of Pedagogy, Taras Shevchenko National University of Kyiv, 60, Vladimirskaya Str., \\ Kyiv, 01033, Ukraine
}

Received: December 9, 2021

Accepted: January 6, 2022 Online Published: January 17, 2022

doi:10.5430/jct.v11n1p264

URL: https://doi.org/10.5430/jct.v11n1p264

\begin{abstract}
The article is devoted to testing the research hypothesis: project management increases the efficiency of managerial decision-making in educational institutions. The authors studied the theoretical and methodological foundations of effective management of educational projects, which confirmed the theoretical possibility of substantiating the hypothesis, namely: they learned, in general, what is the difference between project management and the traditional approach, studied the criteria for the effectiveness of project management, examined and clearly presented approaches to managing an organization, determining principles of the project approach in education and presented the process of designing educational activities. In the study, the authors used both general scientific and specific methods. As an empirical confirmation of the hypothesis, the introduction of project management by educational projects is shown in the example of passing accreditation. For clarity, the authors presented the stages of the project and the Gantt theorem for clarity of its implementation. The experiment showed the effectiveness of the use of educational project management.
\end{abstract}

Keywords: accreditation, education, educational projects, Gantt chart, project management

\section{Introduction}

Modernization of the education system and improving the quality of higher education in modern socio-economic conditions aims to improve the content of the educational process, introduce optimal educational technologies, form new approaches to building the educational environment, and update the educational infrastructure (Prokopenko et al., 2018; Lavrykova et al., 2020; Horodovenko et al., 2021). The authors have already conducted several studies devoted to improving managerial decision-making in education and improving the tools of students' education itself (Gumennykova et al., 2020; Vasiutiak et al., 2021).

The need for the effective development of educational systems at all levels gives rise to many managerial constraints and problems for leaders of educational institutions (Bilovodska et al., 2017; Broshkov et al., 2020). There is a lack of all types of resources (both financial, material and technical) used to organize the educational process (Vasiutiak et al., 2021; Artyukhov et al., 2021). Leaders do not have enough time to make informed management decisions.

In these conditions, it is essential to choose such forms and methods of managing educational institutions that would make it possible to find adequate and practical solutions to a wide variety of problems. The project management methodology is the set of methods that contribute to successful work in a system of constantly changing constraints. The widespread dissemination of this methodology and tangible results in various fields of activity and in all developed and developing countries without exception serve as vivid proof of its effectiveness. Thus, the study's 
hypothesis needs to be tested: project management increases the effectiveness of managerial decision-making in educational institutions. The goal assumes the fulfilment of the following tasks:

- study of the features, characteristics and distinctive features of project management;

- analysis of the criteria for the effectiveness of project management;

- determination of the features of the design approach in education - presentation of the design process of educational activities;

- hypothesis-testing on a real example.

\section{Literature Review}

First of all, it is necessary to consider what is the difference between traditional management and project management. At first glance, there are no remarkable differences between them. The conventional management approach focuses on the course of events, while project management seeks to achieve a particular set goal (George, 2020; Silvius, 2020; Gasemagha \& Kowang, 2021).

Thus, the traditional management approach emphasizes the horizontal relationship between individual jobs and operations; it focuses on the stability of the process as a whole, on minimizing deviations of the process from previously set indicators. At the same time, the action of initiating and setting goals, planning and designing activities remains outside the field of view of project activities.

Before dealing with the definition of this concept, let us consider the main approaches to managing an organization that exists today (Figure 1).

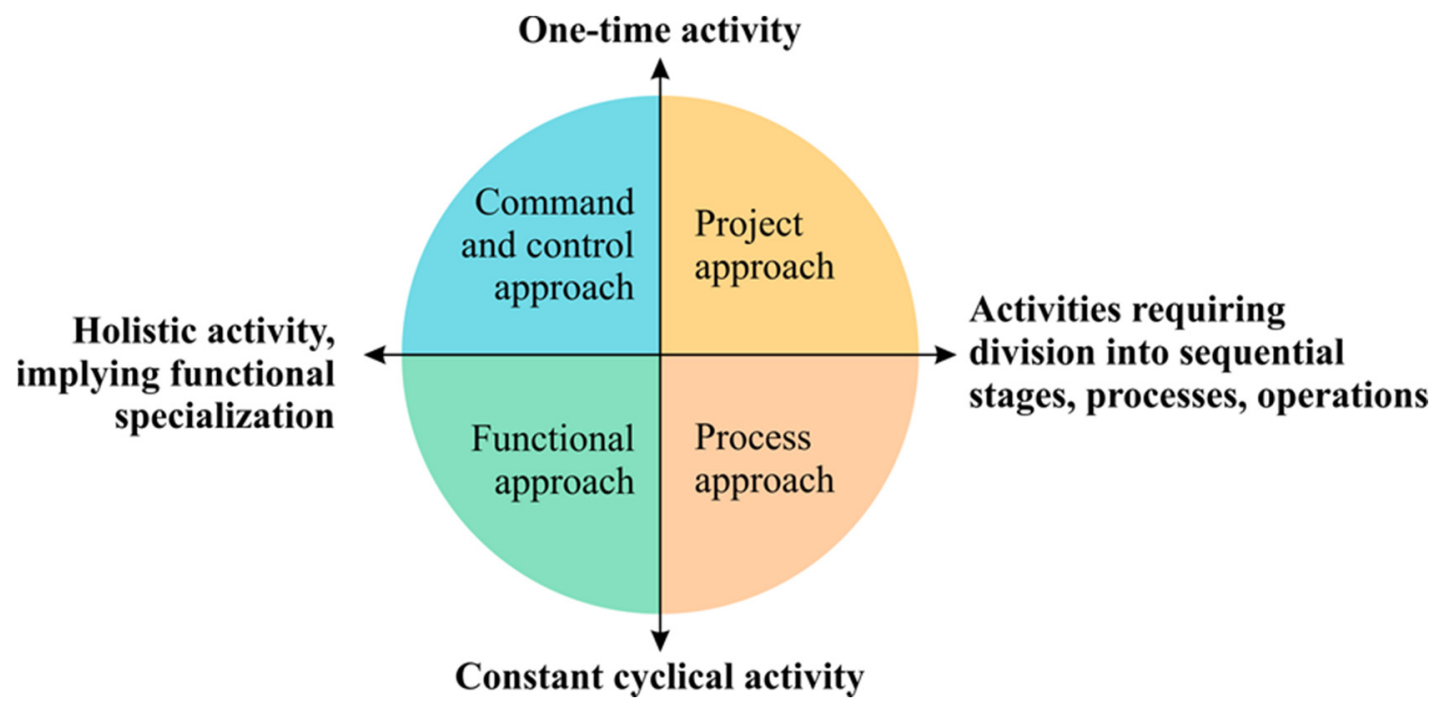

Figure 1. Approaches to Managing an Organization

Sources: Sobotkiewicz, 2020; Caramidaru \& Ionica, 2021; Mazaraki et al., 2021; Recabarren-Domínguez et al., 2022

Command and control approach. Its use is rather limited since it is used for simple one-time actions performed by one person as a rule. It is used in the form of one-time errands.

The project approach is quite common, especially in the field of education, since this activity is continuous and requires functional specialization of a subject or a professionally-oriented nature.

The process approach, on the contrary, is practically not used in education since it is focused on the implementation of individual processes and operations by different groups of people in the production of a standard product. It is used in industrial enterprises with a complex technological cycle or many redistributions.

The functional approach is intended for discrete activities that require division into stages. Project activity is usually a rather complex and lengthy process involving many actors.

In general, project management as a particular management method differs from traditional management in the following: 
1. Traditional management is more focused on the course of actions (events), while project management seeks to achieve a particular set goal.

2. Traditional management is organization-oriented, and project management is results-oriented.

3. An essential link in traditional management is that there is no specific deadline for completing the project, and in project management, the term is strictly limited both in the financial component and in the time scale.

4. In traditional management, planning, distribution by positions takes place, and in project management, the resources used are carefully planned.

5. Traditional management is a work process, and project management is more focused on defining and achieving goals.

6. In traditional management, a general work standard is adopted, and in design management - the acceptance of work at the end of the project.

7. In traditional management, there is a danger of monotony, but in design management, there is variety, priority is given to non-standard.

8. In traditional management, permanent personnel are involved, and in project management, a team can change depending on the project.

For more successful project implementation, careful and thoughtful project management of this project is necessary, which serves as a guarantee of effective operation. The following criteria for the implementation of the project in the education system can be attributed to the guarantee of efficiency:

- integrity associated with the definition of the logistic structure of the project, as a general mechanism of action, as part of an educational organization working to achieve the set goal;

- openness due to the adaptability of the properties of the mechanism to changes in the conditions of its functioning;

- dynamism, necessitating the expansion of the industrial, socio-economic relations of the participants in the educational project;

- hierarchy, focused on harmonizing the interests of the project participants;

- the presence of a set of goals, which requires coordination of the targeted use of all resources in the interests of each subject of the project and the educational organization as a whole;

Structurality implies the dependence of the project's properties on the structure of its elements and the structure of the educational organization.

Next, we need to define the concept of project management in the field of management and pedagogy.

The new International standard for project management ISO 21500:2021 defines a project as a unique set of processes, including coordinated and controlled operations with a start and end date, undertaken to achieve the goal (ISO, 2021).

In the practice of education, the concept of "project activity" has a dual meaning. First, it is interpreted as a method of teaching, and secondly, it is related to the approach to management in the educational system. In our research, we will use this concept in the second sense.

Thus, by an educational project, we will understand a complex, unique activity taking place in conditions of interaction with the external environment, aimed at achieving any educational goal within a certain time frame.

The project approach in education is based on the following principles:

- project activity in modern conditions is becoming a fundamentally new and fundamental way to achieve practical changes in education, the creation of mechanisms for its development;

- project activity integrates a set of activities (educational, scientific, social, organizational, managerial) associated simultaneously with the design and practical implementation of the project concept;

- design in education, in addition to corporate design, includes pedagogical design itself as the setting of educational goals, the construction of developing educational practice, educational technology, methods and means of pedagogical activity;

- design ensures the formation of new educational institutionality, multi-professional teams of developers and implementers of innovative activities, new types of ties within and between academic organizations, principles of 
resource allocation (Glushchenko, 2021; Lock, 2021; Zhuravlova et al., 2021).

Design as a management method. The process of designing educational activities is shown in Figure 2.

It includes the formation of the reasons for the project, the ins and outs, the implementation process, and project management.

Project inputs are the conceptual basis of the project, its environment, implementation conditions, design technologies used, resources. The project's outputs are its results (effects), the recipients of which are various target audiences.

The project implementation process is a complex set of actions aimed at transforming inputs into outputs. Project management is a collection of many types of management activities. Let's highlight the main directions: planning and management of the content, timing and technology of work. Project activity consists of many stages and types of career, each of which has its specifics, method of implementation. The execution of work must proceed rhythmically, without lagging behind the schedule, following the given content and form of the projected educational activity.

Quality control. Various quality standards are imposed on the complex of work on the project: the quality of the resources used, the performance of the work, the finished product in one form or another, etc. All this requires the establishment of indicators, monitoring, and elimination of emerging deviations.

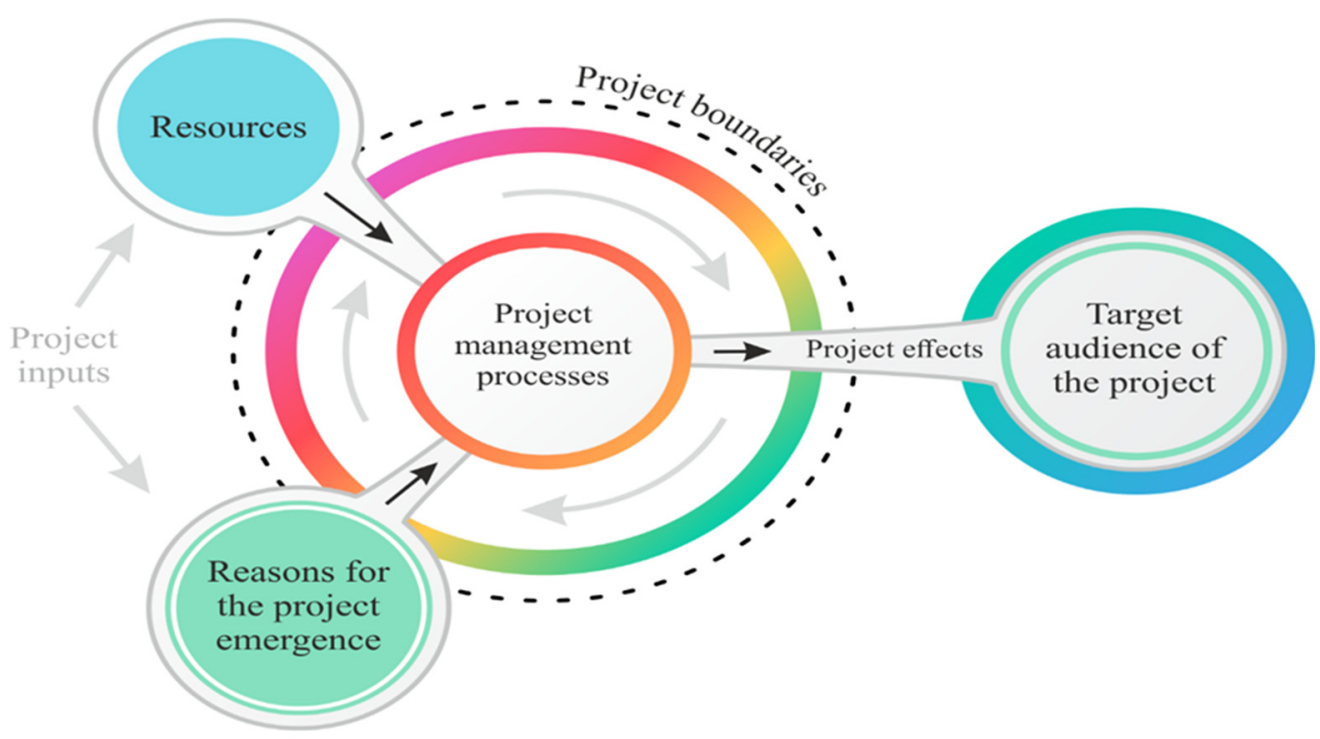

Figure 2. The Process of Designing Educational Activities

Personnel Management. The development and, especially, the implementation of the project is associated with the participation of various human resources in it: personnel of educational and contracting organizations, employees participating in the project based on outstaffing, experts. For each category of employees, specific requirements are imposed on qualifications, amount of work, time of entry into and exit from the project, etc.

It is necessary to consider many human resource management issues: selection, instruction, assessment, labour incentives, control (Alozie, 2019; Yabanci, 2019; Oborina, 2021; Parikh, 2021; Soman, 2021). If third-party personnel are regularly involved in the organization's projects, it is necessary to manage relations with them, monitor their schedule of employment.

Resource management. Project activity requires forecasting, planning, and evaluating various financial, logistical, organizational, informational, educational and methodological resources. It is essential to understand what are the channels for obtaining them. Resource management requires maintaining various forms of reporting, both current and final.

Change management. Implementation of a project is a dynamic process in which changes occur, covering various areas of activity and structural elements. These changes are ongoing, so it is vital to have a clear step-by-step plan at each stage of the project, a scenario of changes. 
Often, changes lead to staff resistance, expressed in direct disobedience or "quiet sabotage", resulting in which the project management needs to apply administrative, economic or moral and psychological methods of team management.

Management of risks. The new content, forms and technologies of educational activities that appear in the course of the project are associated with certain risks. The task of the project managers is to identify risks, analyze them, assess and develop measures to prevent them, eliminate or reduce their negative impact.

The communicative function of project managers is one of the key ones. In the course of implementing an educational project, its leader receives and collects, systematizes a massive amount of information of various kinds, makes decisions on it. Project leaders organize and engage in a wide variety of communications, and they interact with project customers, stakeholders, staff, resource providers, partners, beneficiaries, and infrastructure representatives.

\section{Methods}

In the study, the authors used both general scientific methods: abstract-logical, morphological, abstraction (to study the features, characteristics and distinctive features of project management), systematization, generalization, concretization and comparative analysis (to compare project management and traditional; analysis of project management efficiency criteria), decomposition and induction (to determine the features of the project approach in teaching); methodological techniques of tabular and graphical presentation of research results, theoretical generalization (to form research conclusions), and specific - project management (to develop an example of project management), empirical research and content analysis (hypothesis testing, approbation), graphical method (construction Gantt charts, MS Excel).

\section{Results}

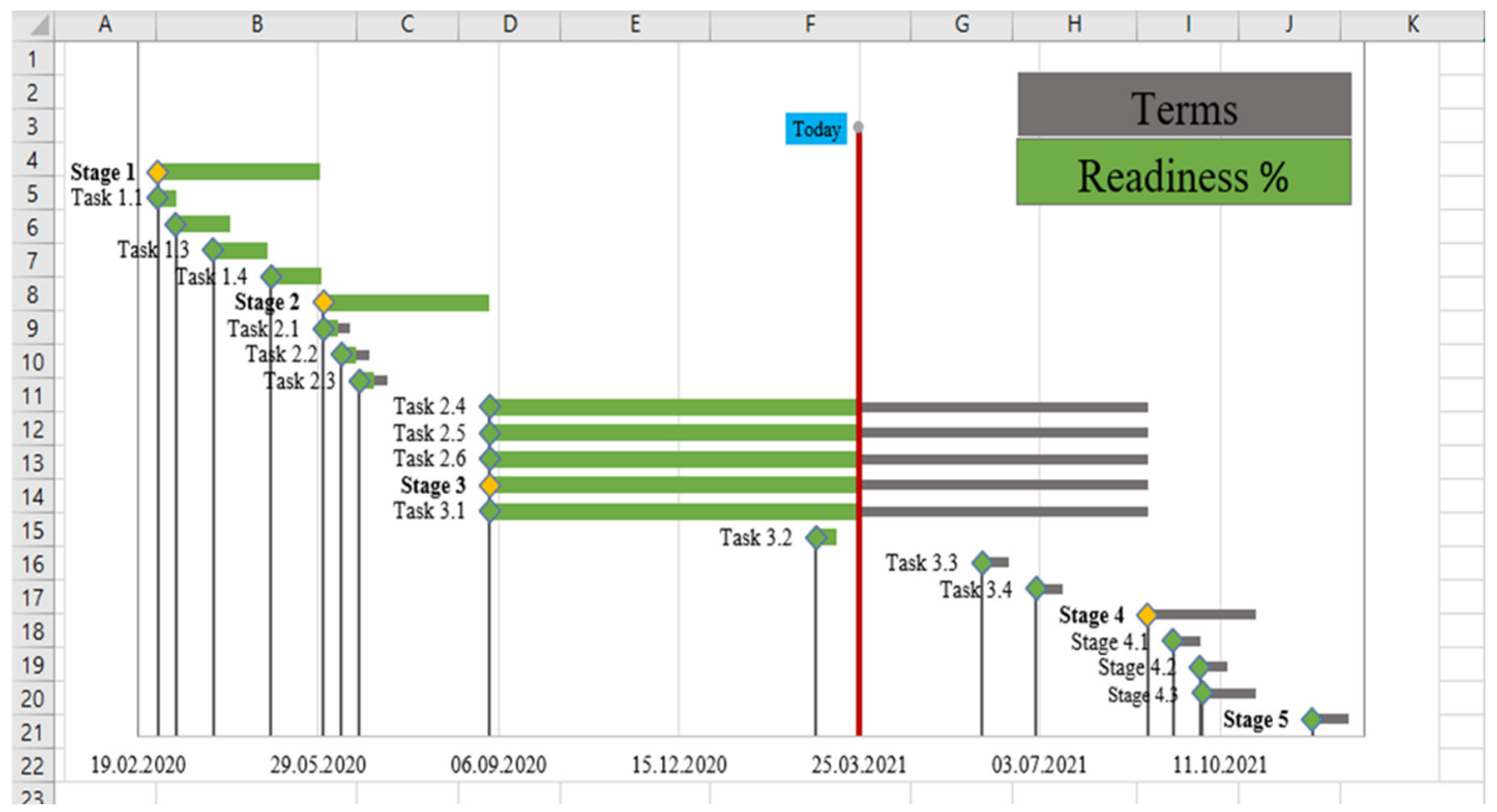

Figure 3. Stages of Educational Project Management (accreditation)

Thus, we believe that almost any activity in a university can and should be considered as a project and project management applied to it. As an example, consider the accreditation of educational programs.

Project goal: to successfully pass accreditation. Let's specify the goal - to get an A or B grade from The National Agency for Higher Education Quality Assurance.

Let's divide the project implementation into stages according to the project approach, adding specifics:

1. Analysis (one and a half years before the start of the accreditation procedure); 
2. Planning (one year) before the start of accreditation;

3. Implementation;

4. Passing accreditation;

5. Analysis of the results, planning the subsequent accreditation.

The detailing is the Gantt diagram (Figure 3), which can be built in MS Excel using the output data (Table 1).

Table 1. Output Data for Managing an Educational Project (building a Gantt chart)

\begin{tabular}{|c|c|c|c|c|c|c|c|}
\hline Stage & Start date & Event & Participants & Terms & Readiness, $\%$ & Readiness, day & Height \\
\hline Today & 25.03 .2021 & Today & & 0 & $0 \%$ & 0 & 70 \\
\hline Stage 1 & 01.03 .2020 & $\begin{array}{l}\text { Stage 1. Analysis (one and a half } \\
\text { years before the start of the } \\
\text { accreditation procedure) }\end{array}$ & $\begin{array}{l}\text { Guarantor, members of the } \\
\text { working group, management of } \\
\text { the university }\end{array}$ & 90 & $100 \%$ & 90 & 65 \\
\hline & & & $\begin{array}{l}\text { Guarantor, members of the } \\
\text { working group, university }\end{array}$ & & & & \\
\hline Task 1.1 & 01.03 .2020 & 1.1 Viewing the evaluation criterion & management & 10 & $100 \%$ & 10 & 62 \\
\hline Task 1.2 & 11.03 .2020 & 1.2 Self-assessment of eligibility & $\begin{array}{l}\text { Guarantor, members of the } \\
\text { working group }\end{array}$ & 30 & $100 \%$ & 30 & 59 \\
\hline Task 1.3 & 01.04 .2020 & 1.3 Identifying Weaknesses & $\begin{array}{l}\text { Guarantor, members of the } \\
\text { working group }\end{array}$ & 30 & $100 \%$ & 30 & 56 \\
\hline Task 1.4 & 03.05 .2020 & 1.4 Student survey & Working group members & 28 & $100 \%$ & 28 & 53 \\
\hline Stage 2 & 01.06 .2020 & $\begin{array}{l}\text { Stage 2. Planning (one year before } \\
\text { the start of accreditation) }\end{array}$ & $\begin{array}{l}\text { Guarantor, members of the } \\
\text { working group, teachers, students }\end{array}$ & 92 & $100 \%$ & 92 & 50 \\
\hline Task 2.1 & 01.06 .2020 & $\begin{array}{l}2.1 \text { Revision of the educational } \\
\text { program plan }\end{array}$ & $\begin{array}{l}\text { Guarantor, members of the } \\
\text { working group, teachers, students }\end{array}$ & 15 & $100 \%$ & 8 & 47 \\
\hline Task 2.2 & 11.06 .2020 & 2.2 Event planning & $\begin{array}{l}\text { Guarantor, members of the } \\
\text { working group, teachers, students }\end{array}$ & 15 & $100 \%$ & 8 & 44 \\
\hline Task 2.3 & 21.06 .2020 & 2.3 Planning student mobility & $\begin{array}{l}\text { Guarantor, members of the } \\
\text { working group, teachers, students }\end{array}$ & 15 & $100 \%$ & 8 & 41 \\
\hline Task 2.4 & 01.09 .2020 & 2.4 Gathering evidence & $\begin{array}{l}\text { Working group members, } \\
\text { teachers }\end{array}$ & 365 & $56 \%$ & 205 & 38 \\
\hline Task 2.5 & 01.09 .2020 & 2.5 Photo and/or video capture & $\begin{array}{l}\text { Working group members, } \\
\text { teachers }\end{array}$ & 365 & $56 \%$ & 205 & 35 \\
\hline Task 2.6 & 01.09 .2020 & $\begin{array}{l}\text { 2.6 Placement of announcements and } \\
\text { results on the website of the } \\
\text { university/social networks of the } \\
\text { department }\end{array}$ & Responsible person & 365 & $56 \%$ & 205 & 32 \\
\hline Stage 3 & 01.09 .2020 & 3. Implementation & $\begin{array}{l}\text { Guarantor, members of the } \\
\text { working group, teachers, students }\end{array}$ & 365 & $56 \%$ & 205 & 29 \\
\hline Task 3.1 & 01.09 .2020 & 3.1 Carrying out planned activities & $\begin{array}{l}\text { Guarantor, members of the } \\
\text { working group, teachers }\end{array}$ & 365 & $56 \%$ & 205 & 26 \\
\hline Task 3.2 & 01.03 .2021 & 3.2 Control of intermediate results & $\begin{array}{l}\text { Guarantor, members of the } \\
\text { working group }\end{array}$ & 10 & $0 \%$ & 11 & 23 \\
\hline Task 3.3 & 01.06 .2021 & 3.3 Control of intermediate results & Guarantee & 15 & $0 \%$ & 0 & 20 \\
\hline Task 3.4 & 01.07 .2021 & $\begin{array}{l}3.4 \text { Drafting a self-assessment } \\
\text { questionnaire }\end{array}$ & $\begin{array}{l}\text { Guarantor, members of the } \\
\text { working group }\end{array}$ & 15 & $0 \%$ & 0 & 17 \\
\hline & & & $\begin{array}{l}\text { Guarantor, members of the } \\
\text { working group, university } \\
\text { management, teachers, students, }\end{array}$ & & & & \\
\hline Stage 4 & 01.09 .2021 & 4. Passing accreditation & $\begin{array}{l}\text { graduates, employers } \\
\text { Guarantor, members of the } \\
\text { working group, university } \\
\text { management, teachers, students, }\end{array}$ & 60 & $0 \%$ & 0 & 14 \\
\hline Stage 4.1 & 15.09 .2021 & 4.1 Working with experts & graduates, employers & 15 & $0 \%$ & 0 & 11 \\
\hline Stage 4.2 & 30.09 .2021 & $\begin{array}{l}4.2 \text { Viewing and responding to expert } \\
\text { reports }\end{array}$ & $\begin{array}{l}\text { Guarantor, members of the } \\
\text { working group }\end{array}$ & 15 & $0 \%$ & 0 & 8 \\
\hline Stage 4.3 & 01.10 .2021 & $\begin{array}{l}\text { 4.3 Reviewing and responding to the } \\
\text { Sectoral expert council report and } \\
\text { decision }\end{array}$ & $\begin{array}{l}\text { Guarantor, members of the } \\
\text { working group }\end{array}$ & 30 & $0 \%$ & 0 & 5 \\
\hline Stage 5 & 01.12 .2021 & 5. Analysis of the results & $\begin{array}{l}\text { Guarantor, members of the } \\
\text { working group }\end{array}$ & 20 & $0 \%$ & 0 & 2 \\
\hline
\end{tabular}




\section{Discussion}

This project approach to accreditation was tested in 2 universities: Taras Shevchenko National University of Kyiv and Izmail State University of Humanities. The performance was about the same to reflect the average result (Figure $4)$.

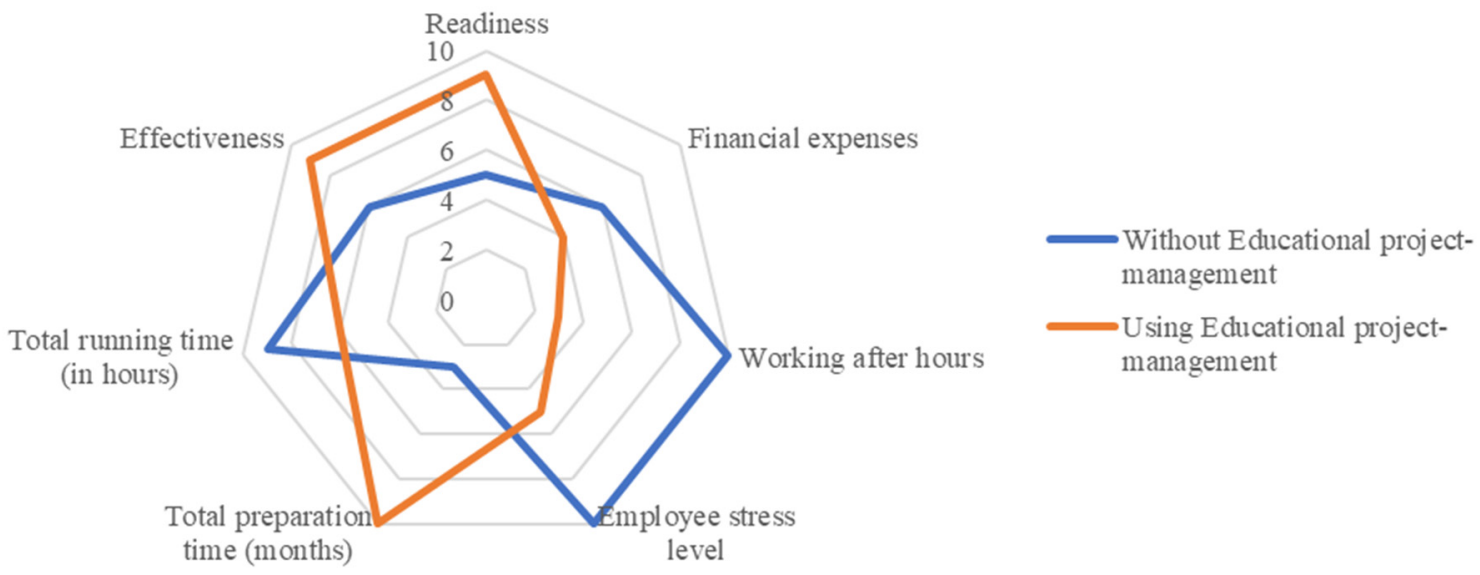

Figure 4. Passing the Accreditation of the Educational Program before and after Applying the Project Approach

It is worth noting the most critical point in the implementation of the project approach to educational projects - the absence of panic and urgent work, which leads to a huge overload on the guarantors of educational programs and the working group. Due to mental and physical exhaustion, some guarantors and members of the working group are required to leave at their own expense to restore balance. The project approach, first of all, is about planning and distribution of responsibilities between performers and in time. Therefore, when the work is carried out in a planned manner and the effectiveness of the project itself, it has a great positive effect on the health of the staff, which is one of the most valuable resources of all universities. The only drawback that can be noted when applying project management is an increase in work time on a project in months, but it takes much fewer hours. Very often, in a hurry, steps that are "unnecessary" from the point of view of performers are skipped, for example, as an analysis of bottlenecks, which in the future allows you to work purposefully to increase efficiency and achieve results. If you skip this particular stage, the time of the work performed in hours increases significantly because a lot of it is wasted on issues that ultimately will not be effective.

\section{Conclusions}

Management of educational projects is the introduction of something into the educational process and other projects that are a prerequisite for the existence and prosperity of the university. Effective project management within the framework of a university is possible when managing interrelated projects within the framework of a program of educational projects. Any university activity should be considered through project management, including a more personal level, for example, writing a syllabus. Project management will allow you to do this systematically, in a planned manner, without unnecessary stress, overnight overtime and haste. Project management within the program's framework will also attract private funding by providing various types of educational services in parallel with the implementation of educational projects.

The practical significance of the research results lies in the fact that the approbation was carried out on a really urgent problem - the accreditation of educational programs so that the guarantors can use it now. We see the prospects for further research in the management of teachers' burnout through the application of project management in their activities. 


\section{References}

Alozie, O. (2019). Human Resource Management. International Journal of Scientific and Research Publications, 9(8), 224-231. http://dx.doi.org/10.29322/IJSRP.9.08.2019.p9235

Artyukhov, A., Omelyanenko, V., \& Prokopenko, O. (2021). University Technology Transfer Network Structure Development: Education and Research Quality Issues. TEM Journal, 10(2), 607-619. http://dx.doi.org/10.18421/TEM102 - 16.

Bilovodska, O., Golysheva, I., Gryshchenko, O., \& Strunz, H. (2017). Theoretical and practical fundamentals of scientific and educational projects: a case of Ukraine. Journal of International Studies, 10(2), 119-128.

Broshkov, M., Forostian, O., Kichuk, Y., Liapa, M., Horbashevska, M., \& Kakhiani, Y. (2020). Management of key performance indicators by heads of higher education institutions. International Journal of Management, 11(5), 286-298. http://dx.doi.org/10.34218/IJM.11.5.2020.028

Caramidaru, I., \& Ionica, A. (2021). In Search of Sustainable Social Impact: A System Dynamics Approach to Managing Nonprofit Organizations Operating in Multi-Project Contexts. JMATEC Web of Conferences, 343(9). https://doi.org/10.1051/matecconf/202134307007

Gasemagha, A., \& Kowang, T. (2021). Project Manager Role in Project Management Success. International Journal of Academic Research in Business and Social Sciences, 11(3), 1345-1355. https://doi.org/10.6007/IJARBSS/v11-i3/9230

George, C. (2020). Unravelling the Critical Role of Project Manager in Project Management Success. International Journal of Science and Research, 9(3), 189-194. https://doi.org/10.21275/SR20302203045

Glushchenko, V. (2021). Project approach in higher engineering education. International Journal of Engineering Technologies and Management Research, 8(3), 36-44. https://doi.org/10.29121/ijetmr.v8.i3.2021.906

Gumennykova, T., Pankovets, V., Liapa, M., Miziuk, V., Gramatyk, N., \& Drahiieva, L. (2020). Applying instructional design methods to improve the effectiveness of blended-learning. International Journal of Management, 211(5), 31-42. https://doi.org/10.34218/IJM.11.5.2020.004

Horodovenko, V., Bilovodska, O., Vatras, V., Kanzafarova, I., \& Melnyk, R. (2021). Improving the quality of higher education based on the positive image of HEE in the social and information space: legal and management aspects. Applied Economics Studies, 39(7). Retrieved from http://ojs.ual.es/ojs/index.php/eea/article/view/4996

ISO. (2021). Project, programme and portfolio management. Retrieved from https://www.iso.org/standard/75704.html

Lavrykova, O., Kuzmenko, N., Demchenko, I., Kovalchuk O., Slipchuk, V., \& Pilevych, O. (2020). Model of formation of future teachers' readiness to work in inclusive education. International Journal of Scientific and Technology Research, 9(2), 410-414.

Lock, D. (2021). A Project-by-Project Approach to Quality. International Journal of Project Management, 19(5), 311-312. https://doi.org/10.1016/S0263-7863(99)00063-0

Mazaraki, A., Tarasiuk, M., Solonenko, Y., Galenko, O., Lysyniuk, M., \& Fayvishenko, D. (2021). Strategic brand management in the market. Applied Economics Studies, 39(5). https://doi.org/10.25115/eea.v39i5.4829

Oborina, A. V. (2021). The evolution of human resource management. Business Strategies, 9(1), $25-31$. https://doi.org/10.17747/2311-7184-2021-1-25-31

Parikh, M. (2021). Human Resource Management. Research in Personnel and Human Resources Management, 1500(48), 24-27.

Prokopenko, O., Holmberg, R., \& Omelyanenko, V. (2018). Information and communication technologies support for the participation of universities in innovation networks (comparative study). Innovative Marketing, 14(3), 17-29. https://doi.org/10.21511/im.14(3).2018.03

Recabarren-Domínguez, E., López, F. A., Ferriol, F., \& Gatica, G. (2021). A Methodological Proposal for Managing Operational Risk by Integrating Agility. Smart Innovation, Systems and Technologies, 255, 319-325. https://doi.org/10.1007/978-981-16-4884-7_26

Silvius, G. (2020). The Relation Between Sustainable Project Management and Project Success. International Journal of Management and Sustainability, 9(4), 218-238. https://doi.org/10.18488/journal.11.2020.94.218.238 
Sobotkiewicz, D. (2020). Functional or process approach in managing the organization. decision dilemmas of modern multi-entity organizations. Scientific papers of Silesian university of technology, 149, 609-619. https://doi.org/10.29119/1641-3466.2020.149.50

Soman, D. (2021). Human Resource Management: For Humans. NHRD Network Journal, 14(4). https://doi.org/10.1177/2631454120982115

Vasiutiak, I., Babych, O., Shoptenko-Ivanova, O., Zhuravlova, A., Myroniuk, N., \& Nebesnyk, A. (2021). The Role of Sports Dance in Ensuring the Motor Activity of Students. International Journal of Human Movement and Sports Sciences, 9(6), 1299-1305. https://doi.org/10.13189/saj.2021.090625.

Yabanci, O. (2019). From human resource management to intelligent human resource management: a conceptual perspective. Human-Intelligent Systems Integration, 1, 101-109. https://doi.org/10.1007/s42454-020-00007-x

Zhuravlova, Y., Kichuk, N., Zhuravska, N., Yakovenko, O., Zhytnyk, V., \& Yashchuk, S. (2021). The Problem Field of Professional (Vocational) Education: Innovations and Ways to Improve. Studies of Applied Economics, 39(5). https://doi.org/10.25115/eea.v39i5.5274

\section{Copyrights}

Copyright for this article is retained by the author(s), with first publication rights granted to the journal.

This is an open-access article distributed under the terms and conditions of the Creative Commons Attribution license (http://creativecommons.org/licenses/by/4.0/). 